Original Article

\title{
Antimalarial potential of homeopathic medicines against schizont maturation of Plasmodium berghei in short-term in vitro culture
}

\author{
Aswathy Rajan and Upma Bagai \\ Department of Zoology, Panjab University, Chandigarh, India
}

\begin{abstract}
In vitro assessment of the susceptibility of Plasmodium to antimalarial drugs represents a major research breakthrough that paved the way for the understanding of the parasite, and rapid screening of the effectiveness of antimalarial drugs. In the present study, a preliminary screening of the antiplasmodial activity of the mother tincture $(\phi)$ and various potencies $(6 \mathrm{cH}, 30 \mathrm{cH}, 200$ $\mathrm{cH})$ of homeopathic medicines China officinalis, Chelidonium majus and Arsenicum album was performed by means of the in vitro schizont maturation inhibition assay. Significant reduction of the growth of intra-erythrocyte stages of $P$. berghei was observed with decreasing dilutions of $\phi$ and the various potencies of Chin, Chel and Ars with dose-dependent effect. Maximum schizont maturation inhibition (80\%) was observed with Chin $\phi(1: 1)$, Chin $30 \mathrm{cH}(1: 1,1: 2)$ and Chel $30 \mathrm{cH}$ $(1: 1)$. The standard drug chloroquine (CQ) at $10-\mu \mathrm{M}$ concentration exhibited $95.4 \pm 1.6 \%$ inhibition of schizont maturation. Ars 30 (1:1) also exhibited strong antiplasmodial efficacy, with $75.5 \pm 2.6 \%$ of schizont inhibition. The presence of free merozoites with Ars $200 \mathrm{cH}$ and weak schizont inhibition activity (40-45\%) points to the ability of the parasite to survive in the given drug pressure.
\end{abstract}

Keywords: Homeopathy; Plasmodium berghei: China officinalis; Chelidonium majus; Arsenicum album

\section{Introduction}

Research on malaria has benefited considerably from technical advances in the culture systems for Plasmodium [1]. Continuous in vitro cultivation of human malaria parasite P. falciparum was first reported by Trager and Jenson in 1976. This paved the way for the development of microtiter plate assay for the determination of antiplasmodial activity, in which the parasite growth is assessed by incubating $(21 \mathrm{~h})$ culture in RPMI-1640 medium supplemented with various antibiotics [2]. After the establishment of continuous in vitro culture of $P$. falciparum, studies on invasion inhibition studies were conducted with different species of the malaria parasite. Ladda et al gave a detailed fine structural account of the process of erythrocyte invasion by merozoites of $P$. berghei yoelii and P. gallinaecum [3]. McNally et al described in vitro erythrocyte invasion assays for two species of rodent malaria, namely $P$. berghei and $P$. chabaudi. They demonstrated an in vitro preference for the reticulocytes for invasion by both species [4].

Short-term invasion inhibition assays might be used to assess the susceptibility to antimalarial drugs. In vitro studies were also performed to determine the resistance of $P$. falciparum to standard antimalarial drugs chloroquine, quinine, amodiaquine, halofantrine, mefloquine, cycloguanil and pyrimethamine [5]. 
The present study aimed to study in vitro the inhibition of $P$. berghei schizont maturation in the presence of various homeopathic drugs, namely China officinalis, Chelidonium majus, and Arsenicum album. According to Bellavite et al, as high dilutions (HD) of homeopathic preparations are able to evoke a specific and global secondary healing reaction, they might represent potentially effective therapeutic agents [6].

Also the first in vitro study on HD ever published in a mainstream science journal supported the effects of homeopathic solutions in vitro. Those authors suggested that extremely diluted solutions of antiserum against human IgE were able to induce basophil degranulation in vitro [7]. In vitro research using HD was also conducted with molecular or cellular systems. This approach reduces the complexity of the models, and allows for a higher degree of standardization of the drugs compared to clinical research, and might eventually provide model systems to reveal the mechanism of action of HD, traditionally considered to be devoid of pharmacologically active molecules [8]. Extensive in vitro studies were performed by a team of researchers at the University of Utrecht using cultured mammal cells, primarily to understand the mechanism of action of homeopathic formulations [9].

\section{Materials and methods}

\section{Maintenance of the parasite strain}

White Swiss mice Mus musculus strain BALB/c, weighing 22-26 g, aged 4-6 weeks old, of either gender, obtained at Central animal house, Panjab University, Chandigarh, India, were used for parasite maintenance. The mice were maintained on a standard pellet diet and water ad libitum. The strain of P. berghei (NK-65) was maintained by means of intraperitoneal inoculation of $1 \times 10^{6}$ infected red blood cells (RBCs) to naïve mice [10]. The treatment of mice followed the guidelines of the animal ethics committee (Reg. No. 45/1999/CPCSEA), Panjab University, Chandigarh. The parasitemia was checked by preparing Giemsastained thin blood smears on slides following incision of the tail vein of the infected mice.

\section{Experimental drugs}

Homeopathic mother tincture $(\phi)$ and different potencies $(6 \mathrm{cH}, 30 \mathrm{cH}$ and $200 \mathrm{cH})$ of China officinalis, Chelidonium majus and Arsenicum album manufactured by Dr. Reckeweg and Co. GmbH D.64625, Bensheim, Germany, were used in the present study.

Chloroquine (CQ - chloroquine phosphate suspension containing $50 \mathrm{mg}$ of base, Lariago ${ }^{\circledR}$ ) manufactured in India, was used as standard positive control. The required concentration of $10 \mu \mathrm{M}$ was prepared according to the method described by the World Health Organization (WHO) [11].

\section{In vitro schizont inhibition assay}

Short-term in vitro culture of $P$. berghei blood stages was performed according to modified Trager and Jensen method [2]. The in vitro antimalarial efficacy of the homeopathic medicines was determined by means of schizont inhibition assay [11].

\section{Short-term in vitro culture}

RPMI-1640 medium (Gibco) supplemented with 0.06\% (w/v) HEPES, 5\% (w/v) sodium bicarbonate; antibiotics - gentamycin $(50 \mu \mathrm{g} / \mathrm{ml})$, penicillin $(100 \mu \mathrm{l} / \mathrm{ml})$ and streptomycin $(100 \mu \mathrm{g} / \mathrm{ml})$ was used as culture medium $(\mathrm{pH}$ 7.4). Ten percent (v/v) inactivated fetal calf serum (FCS) was added to the incomplete medium to prepare the complete medium. 


\section{Preparation of normal and $P$. berghei-infected erythrocytes}

Blood from normal mice and $P$. berghei infected mice was collected aseptically in citrate saline and centrifuged at 1,000 g for $10 \mathrm{~min}$ for pellet separation. The pellet was washed with the incomplete medium. Parasite pellet from infected blood containing rings at lower layer was aspirated. Infected and normal erythrocytes were mixed in a proportion to achieve a parasitemia level of $2-4 \%$ at $0 \mathrm{~h}$.

\section{In vitro antiplasmodial activity of the homeopathic drugs}

The antiplasmodial activity of various dilutions (1:1, 1:2 and 1:4) of the mother tincture and different potencies of the homeopathic drugs was checked by assessing the inhibition of schizonts following incubation for $21 \mathrm{~h}$ (WHO, 2001). One $\mathrm{ml}$ of the complete medium contained $50 \mu \mathrm{l}$ of homeopathic drugs Chin, Chel, or Ars $(\phi, 6 \mathrm{cH}, 30 \mathrm{cH}$, and $200 \mathrm{cH})$ diluted in different ratios. Each drug was checked in duplicate in a 24-well microtiter plate. After shaking gently the titer plate, $0 \mathrm{~h}$ smears were prepared, and the culture plate was incubated at $37{ }^{\circ} \mathrm{C}$ in a candle jar $\left(5 \% \mathrm{CO}_{2}, 17 \% \mathrm{O}_{2}, 78 \% \mathrm{~N}_{2}\right)$ according to Trager and Jensen's (1976) method. After $21 \mathrm{~h}$ of incubation, the smears from each well were prepared, fixed in methanol, and stained with Giemsa dye. Inhibition of schizont development by comparison to the control wells was determined by following equation: $100-[\mathrm{A} / \mathrm{B} \times 100]$, where $\mathrm{A}$ is the average number of schizonts in the drug treated well, and $\mathrm{B}$ is the average number of schizonts in the infected control wells.

The experiment was repeated three times to validate the results. The data are expreesed as mean and standard deviation (SD). The statistical significance and intergroup difference in schizont maturation inhibition by the various drugs were assessed by paired Student's t-test. Comparison was performedbetween the test and control groups of mice with $p$ value $<0.05$ as statistically significant.

\section{Results}

\section{In vitro schizont maturation inhibition assay}

The short-term in vitro culture of $P$. berghei was tested as to the antiplasmodial efficacy of the homeopathic medicines. Three different dilutions (1:1, 1:2 and 1:4) of each drug were used to check the drug-dependent effect on intra-erythrocyte development of $P$. berghei in vitro.

The lower layer of hematocrit consisting of rings and trophozoites were used for initiating culture. $2.8 \%$ infection was observed at $0 \mathrm{~h}$ (Fig. 1A). After $21 \mathrm{~h}$ of incubation at $37^{\circ} \mathrm{C}$, the culture was terminated and development of schizonts was checked. There was almost fivefold increase in the parasitaemia (14.7\%) after $21 \mathrm{~h}$ of incubation (Fig. 1B and C). 

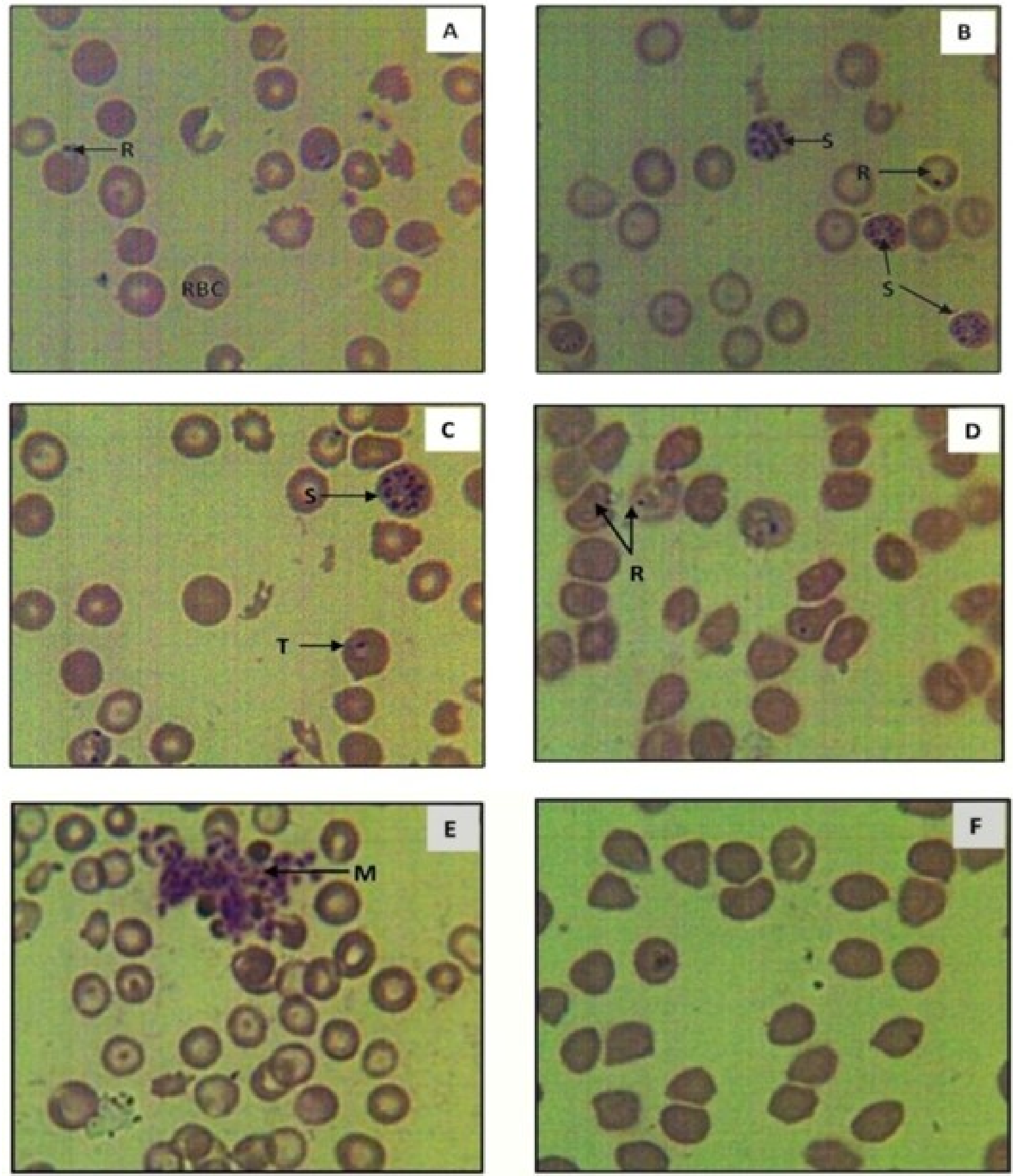

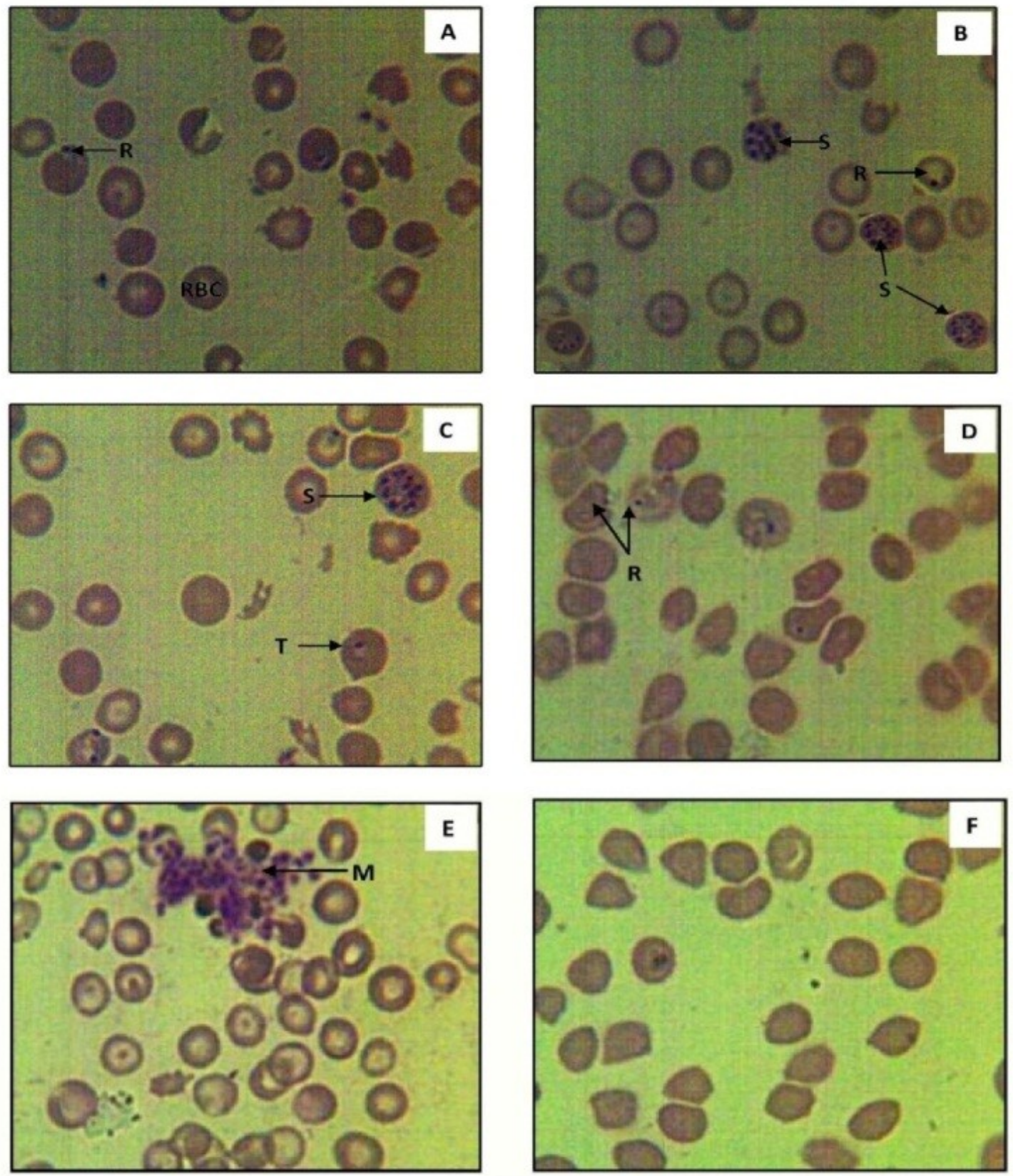

Figure 1: Giemsa-stained blood smears (100×) of $P$. berghei in vitro culture at $0 \mathrm{~h}(\mathrm{~A}), 21 \mathrm{~h}(\mathrm{~B}, \mathrm{C})$ along with

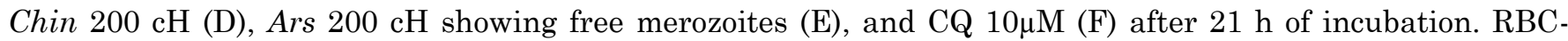
normal red blood cell, R - ring, T - trophozoite, S - schizont, M - free merozoites.

The mother tincture and different potencies of Chin, Chel, and Ars inhibited the development of intraerythrocyte stages of $P$. berghei in vitro in a dose dependent manner (Fig. 2, 4, 6). Decrease in schizont maturation inhibition was observed with increase in the dilution of drug (Fig. 3). Maximum schizont maturation inhibition $(80.2 \pm 2.1 \%)$ was observed in the presence of Chin $\phi$. Chin $30 \mathrm{cH}$ exhibited $80 \%$ inhibition of schizont maturation after $21 \mathrm{~h}$ of incubation. Chin $200 \mathrm{cH}$ exhibited $(50.0 \pm 0.8) \%$ of schizont maturation inhibition. 


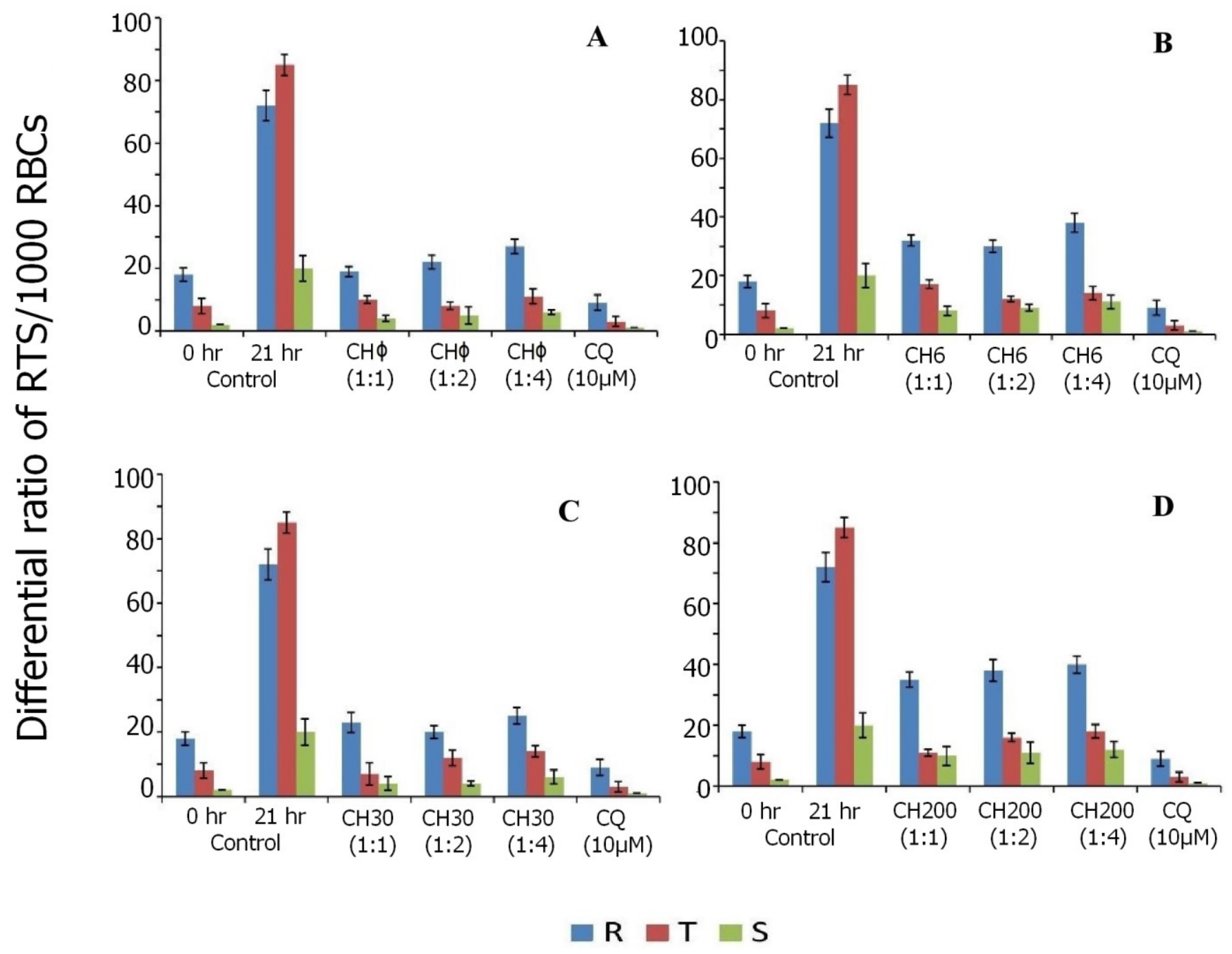



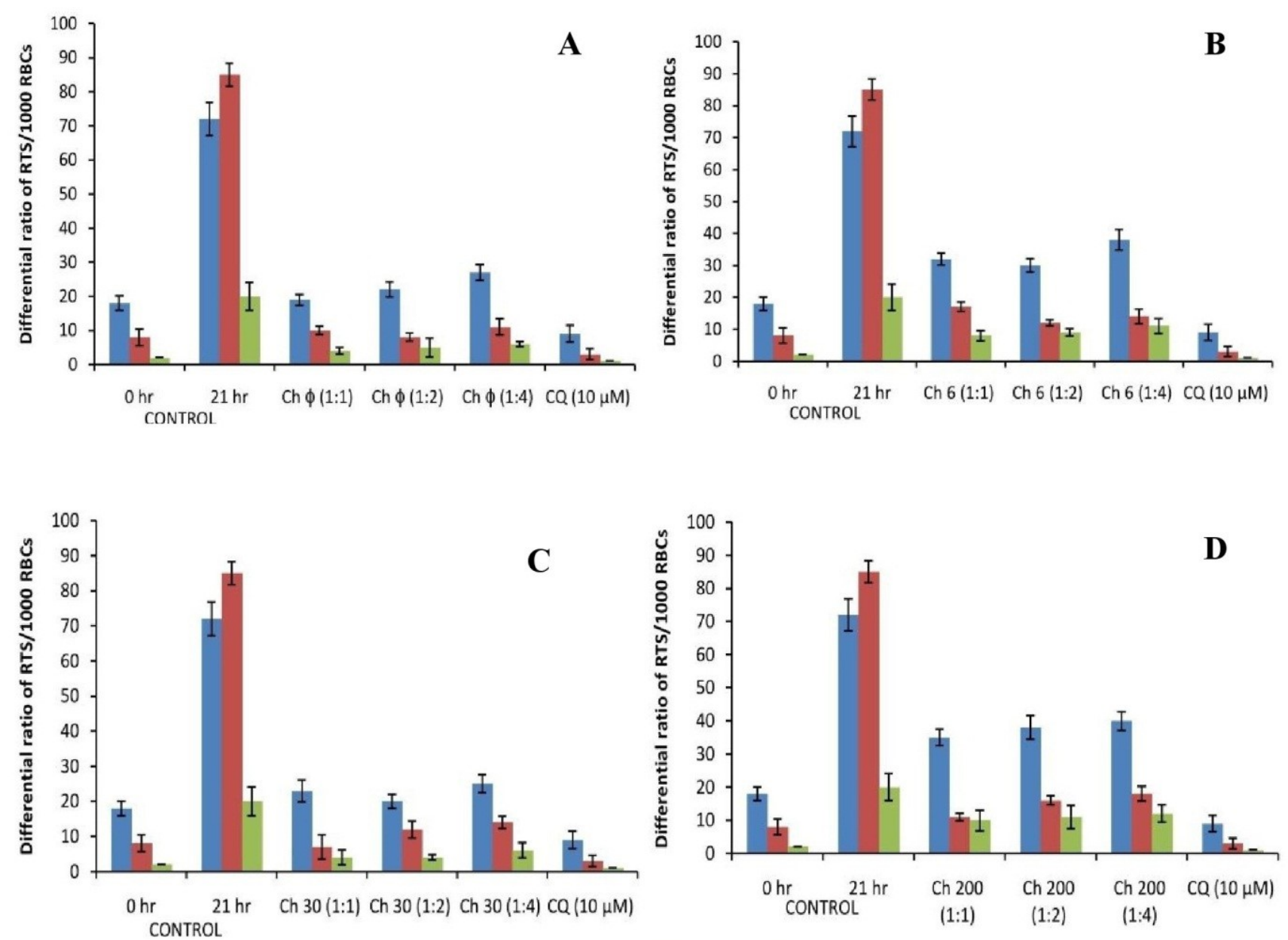

$\because \mathrm{R} \backsim \mathrm{T}$

Figure 2: Histogram showing dose-dependent effect on intra-erythrocyte stages of $P$. berghei in vitro after $21 \mathrm{~h}$ of incubation in the presence of Chin $\phi(\mathrm{A})$ and its various potencies: Chin $6 \mathrm{cH} \mathrm{(B),} \mathrm{Chin} 30 \mathrm{cH} \mathrm{(C)} \mathrm{and} \mathrm{Chin}$ $200 \mathrm{cH}(\mathrm{D})$ along with positive control CQ $(10 \mu \mathrm{M})$. R - rings, T - trophozoites, S - schizonts. Data are expressed as the mean $\pm \mathrm{SD}$ of three separate experiments. $=\mathrm{R}=\mathrm{T}=\mathrm{S}$ 


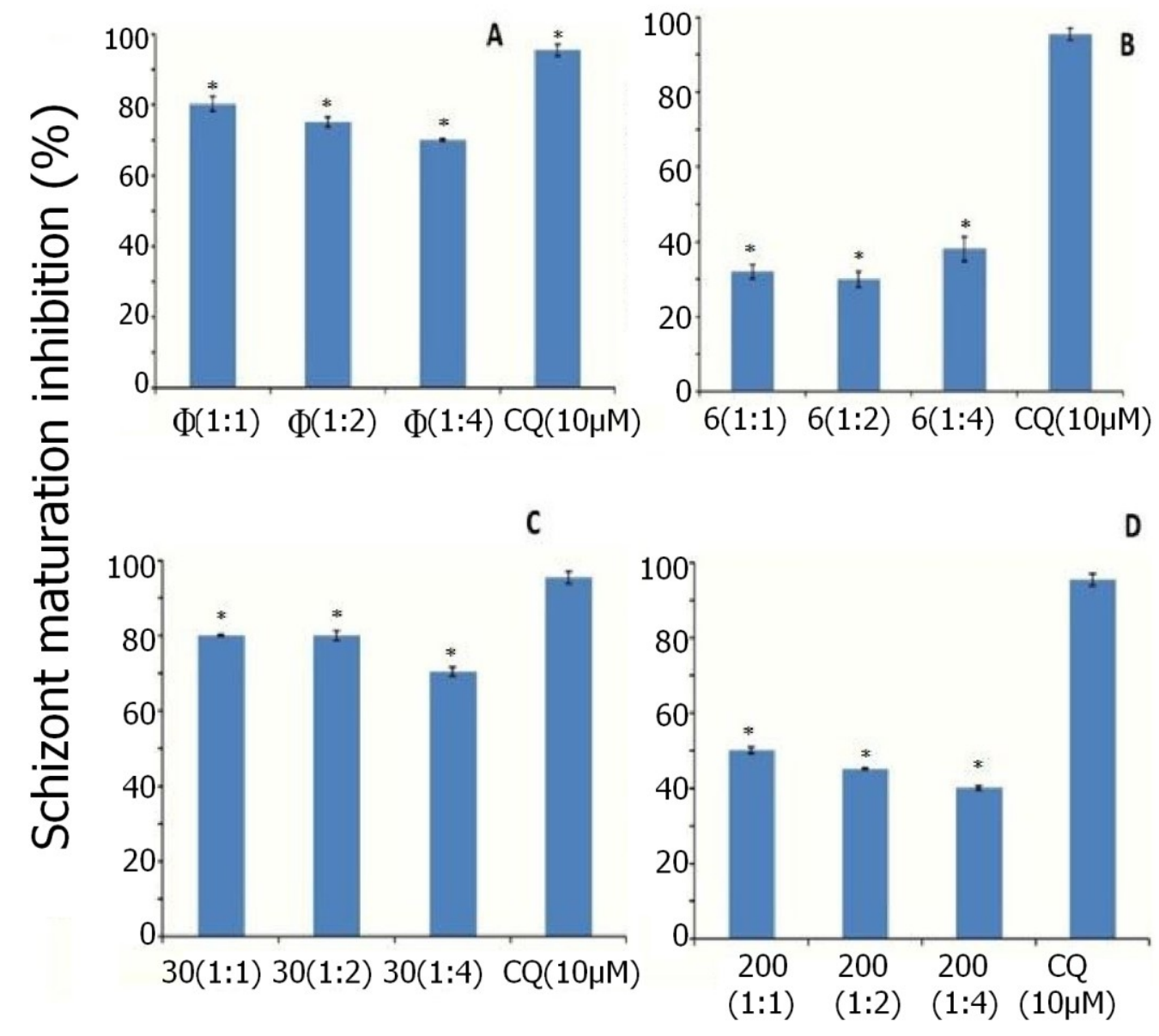

Figure 3: [TT1]Histogram showing schizont maturation inhibition of $P$. berghei in vitro after $21 \mathrm{~h}$ of incubation in the presence of Chin $\phi(\mathrm{A})$ and its various potencies: Chin $6 \mathrm{cH} \mathrm{(B),} \mathrm{Chin} 30 \mathrm{cH} \mathrm{(C)}$ and Chin $200 \mathrm{cH}$ (D) along with positive control CQ $(10 \mu \mathrm{M})$. Data are expressed as the mean \pm SD of three separate experiments. $\mathrm{p}<0.05$ in comparison to positive control CQ $(10 \mu \mathrm{M})$ is shown as * (statistically significant). 

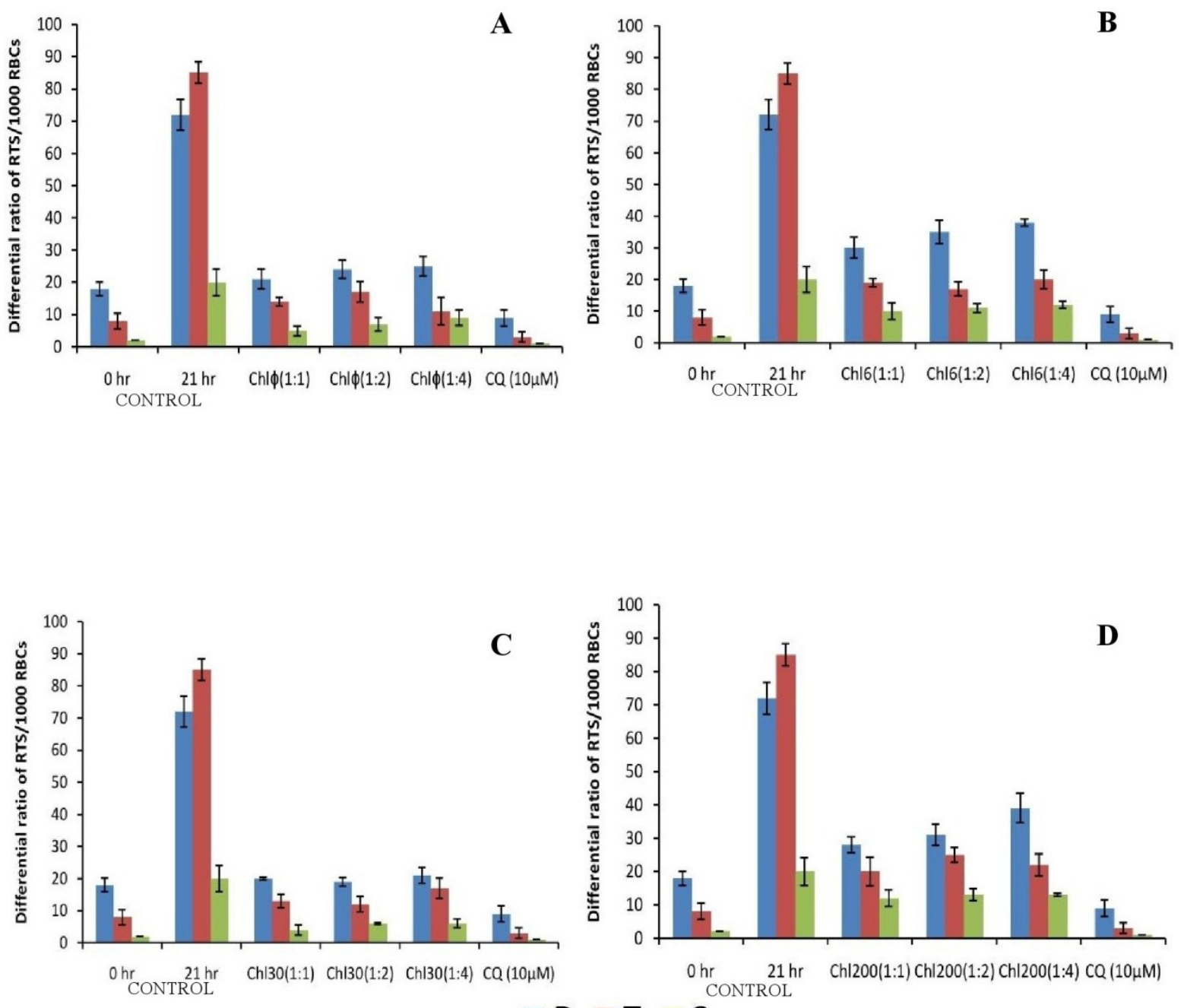

$\mathrm{R}=\mathrm{T} \square \mathrm{S}$ 

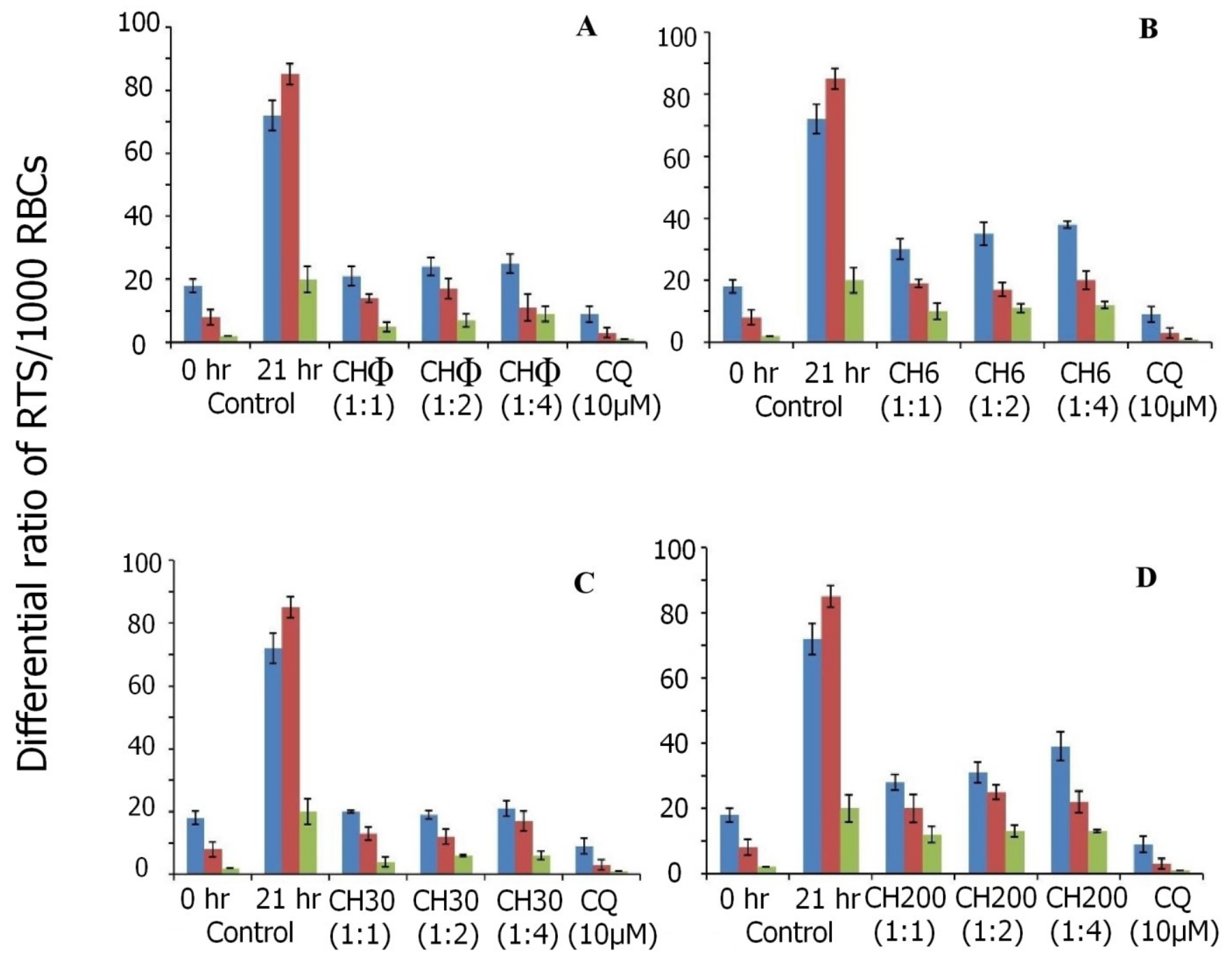

Figure 4: Histogram showing dose-dependent effect on intra-erythrocyte stages of $P$. berghei in vitro after $21 \mathrm{~h}$ of incubation in the presence of Chel $\phi(\mathrm{A})$ and its various potencies: Chel 6 (B), Chel $30 \mathrm{cH}(\mathrm{C})$ and Chel 200 $\mathrm{cH}(\mathrm{D})$ along with positive control CQ $(10 \mu \mathrm{M})$. R - rings, T - trophozoites, S - schizonts. Data are expressed as the mean $\pm \mathrm{SD}$ of three separate experiments. $=\mathrm{R}=\mathrm{T}=\mathrm{S}$ 


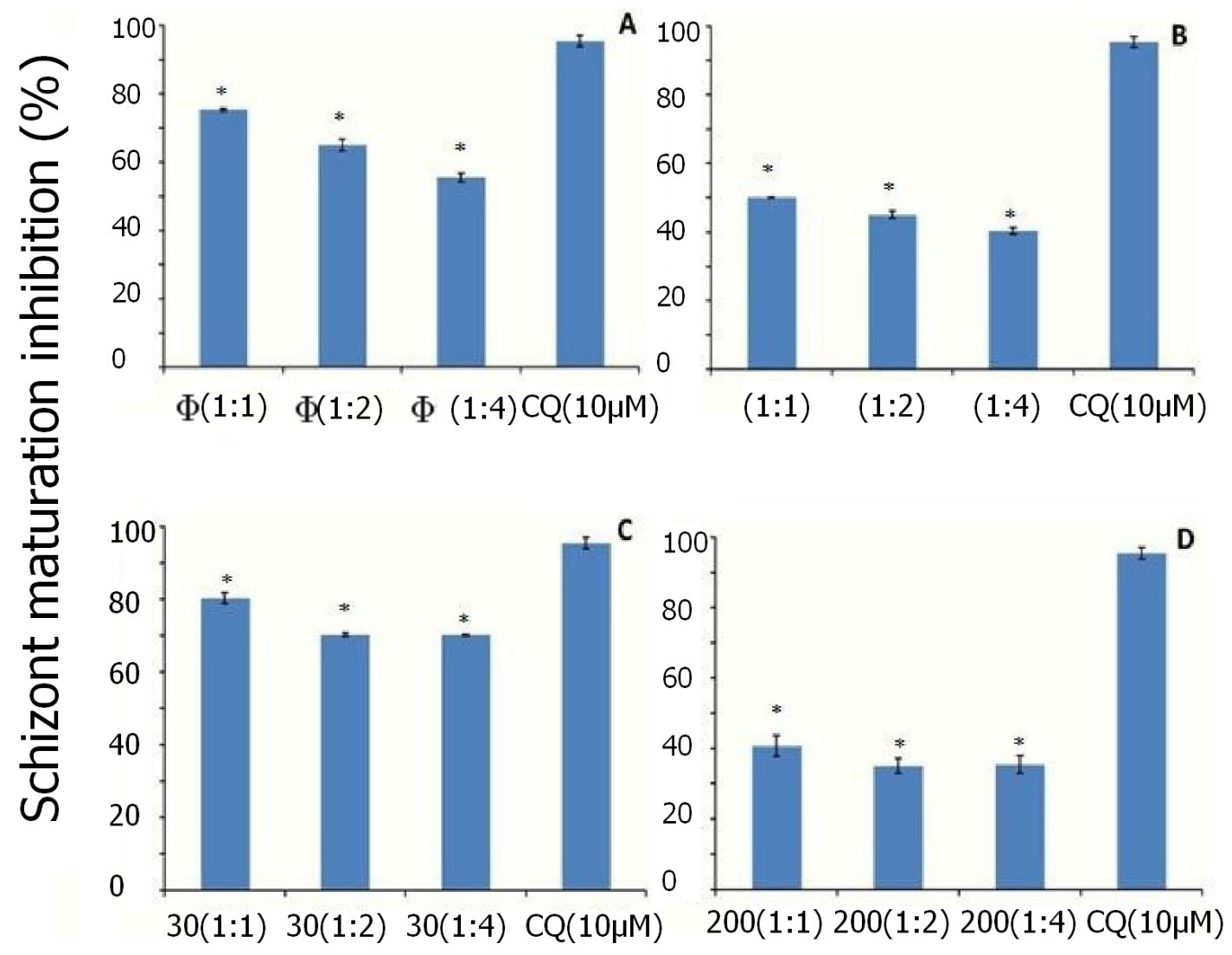

Figure 5: [TT2]Histogram showing schizont maturation inhibition of $P$. berghei in vitro after $21 \mathrm{~h}$ of incubation in the presence of Chel $\phi(\mathrm{A})$ and its various potencies: Chel $6 \mathrm{cH}(\mathrm{B})$, Chel $30 \mathrm{cH} \mathrm{(C),} \mathrm{Chel} 200 \mathrm{cH}$ (D) along with positive control CQ $(10 \mu \mathrm{M})$. Data are expressed as the mean \pm SD of three separate experiments. $p<0.05$ in comparison to positive control CQ $(10 \mu \mathrm{M})$ is shown as * (statistically significant). 


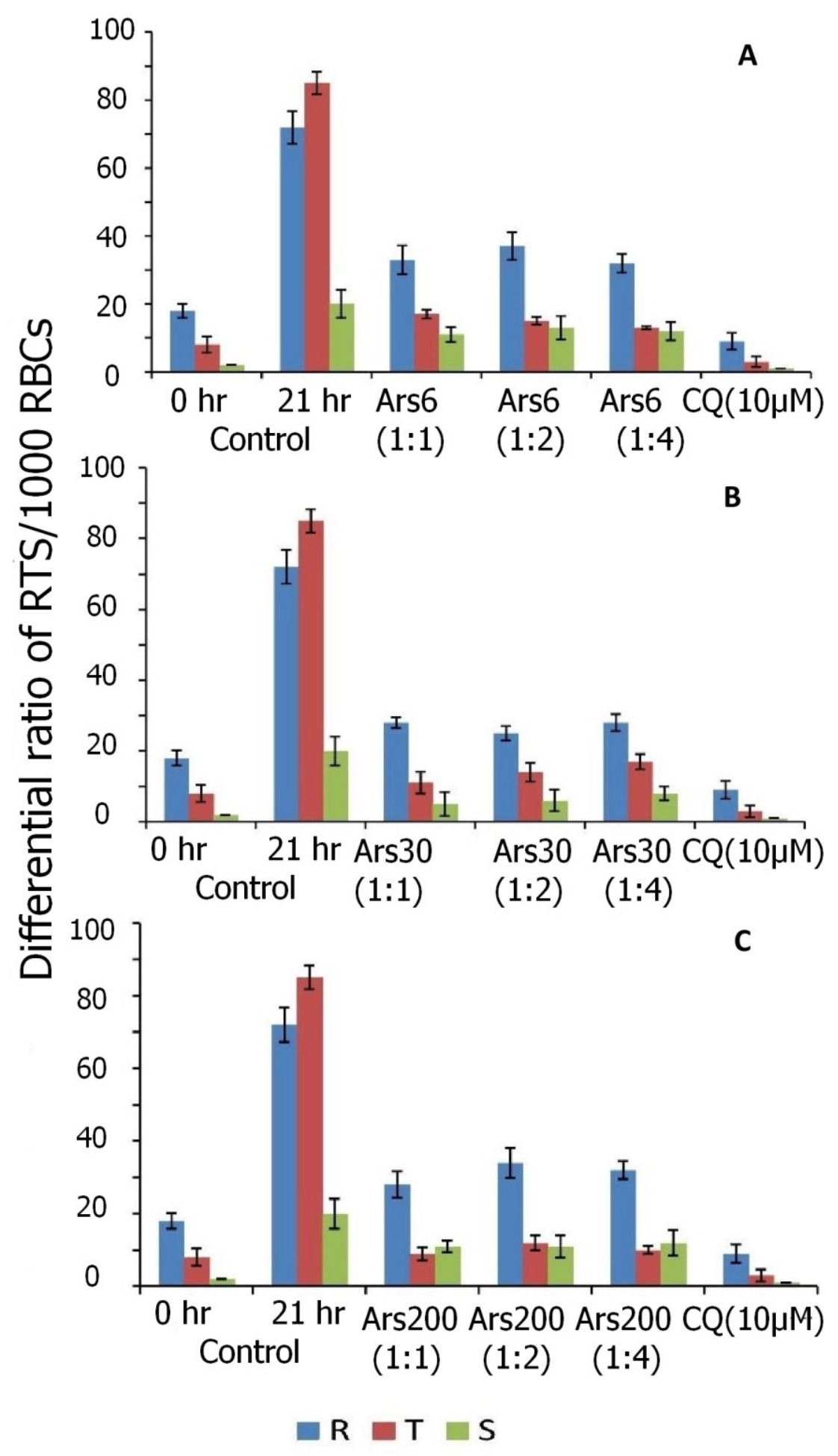



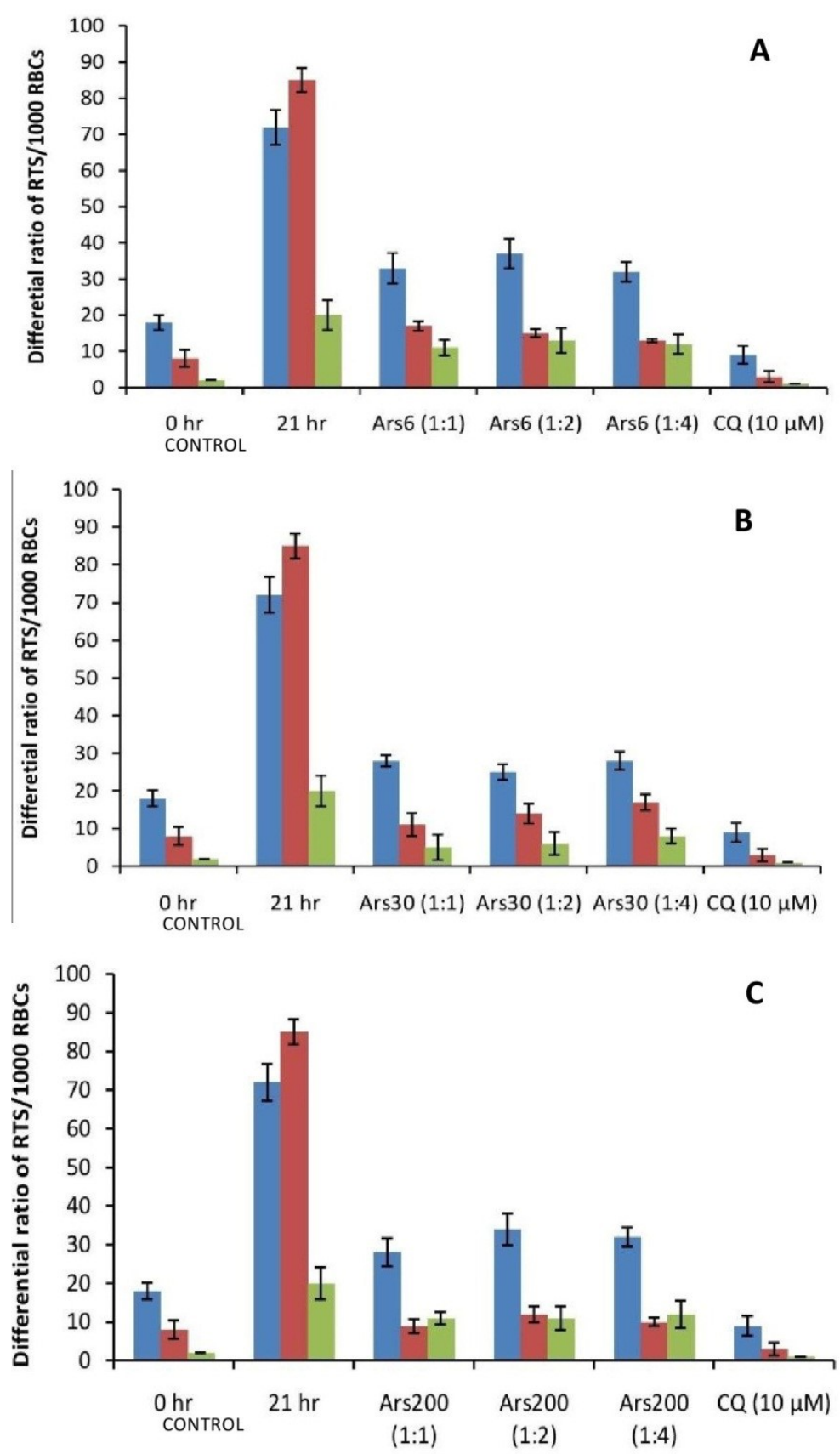

$\because \mathrm{R} \backsim \mathrm{T} \square \mathrm{S}$

Figure 6: Histogram showing dose-dependent effect on intra-erythrocyte stages of $P$. berghei in vitro after $21 \mathrm{~h}$ of incubation in the presence of Ars $6 \mathrm{cH}$ (A), Ars $30 \mathrm{cH}$ (B) and Ars $200 \mathrm{cH}$ (C) along with positive control CQ $(10 \mu \mathrm{M}) . \mathrm{R}$ - rings, $\mathrm{T}$ - trophozoites, $\mathrm{S}$ - schizonts. Data are expressed as the mean $\pm \mathrm{SD}$ of three separate experiments. $=\mathrm{R}=\mathrm{T}=\mathrm{S}$ 

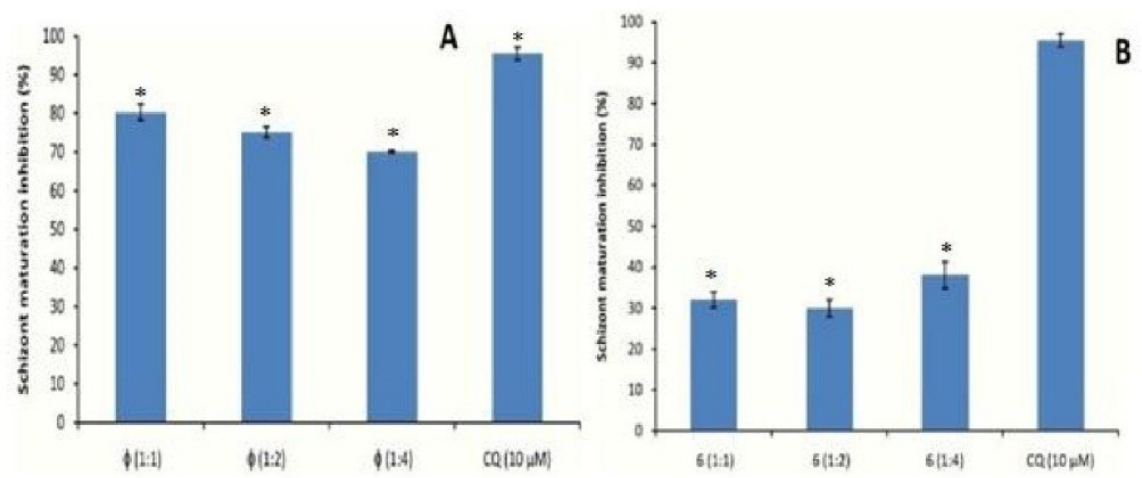

C

D
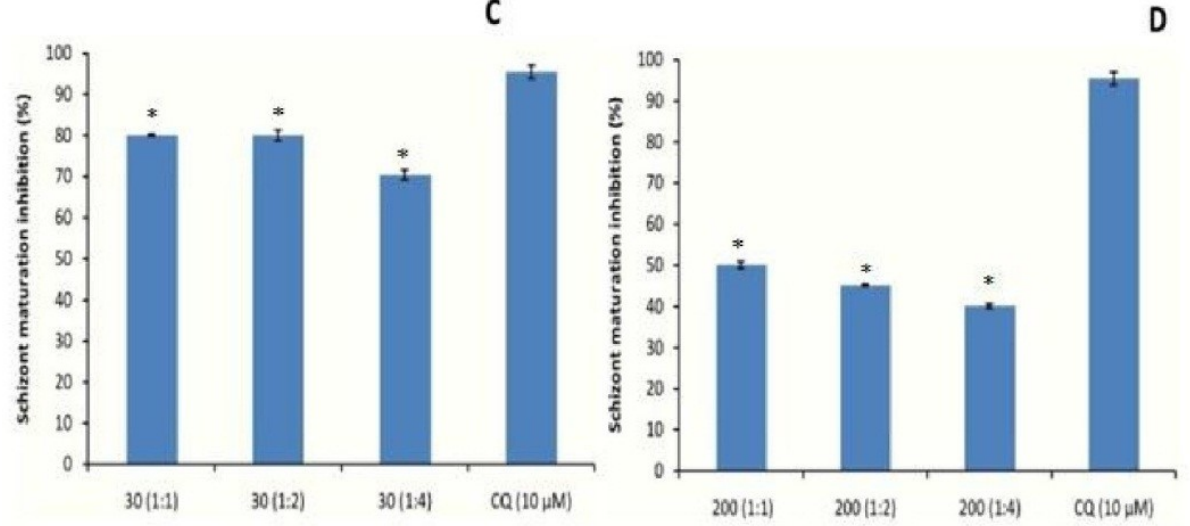

Figure 3: [TT3]Histogram showing schizont maturation inhibition of $P$. berghei in vitro after $21 \mathrm{~h}$ of incubation in the presence of Chin $\phi(\mathrm{A})$ and its various potencies: Chin $6 \mathrm{cH}(\mathrm{B})$, Chin $30 \mathrm{cH}$ (C) and Chin $200 \mathrm{cH}$ (D) along with positive control CQ $(10 \mu \mathrm{M})$. Data are expressed as the mean $\pm \mathrm{SD}$ of three separate experiments. $\mathrm{p}<0.05$ in comparison to positive control CQ $(10 \mu \mathrm{M})$ is shown as * (statistically significant).

A total of $80.2 \pm 1.5 \%$ inhibition of schizont maturation was observed in the presence of Chel $30 \mathrm{cH}$. As the dilution of the drug was increased, decline in the schizont maturation inhibition was observed in $\phi$ and the various potencies (Fig. 5). Chloroquine (CQ) $10 \mu \mathrm{M}$ exhibited $95.4 \pm 1.6 \%$ inhibition of schizont maturation after $21 \mathrm{~h}$ of incubation in vitro. 

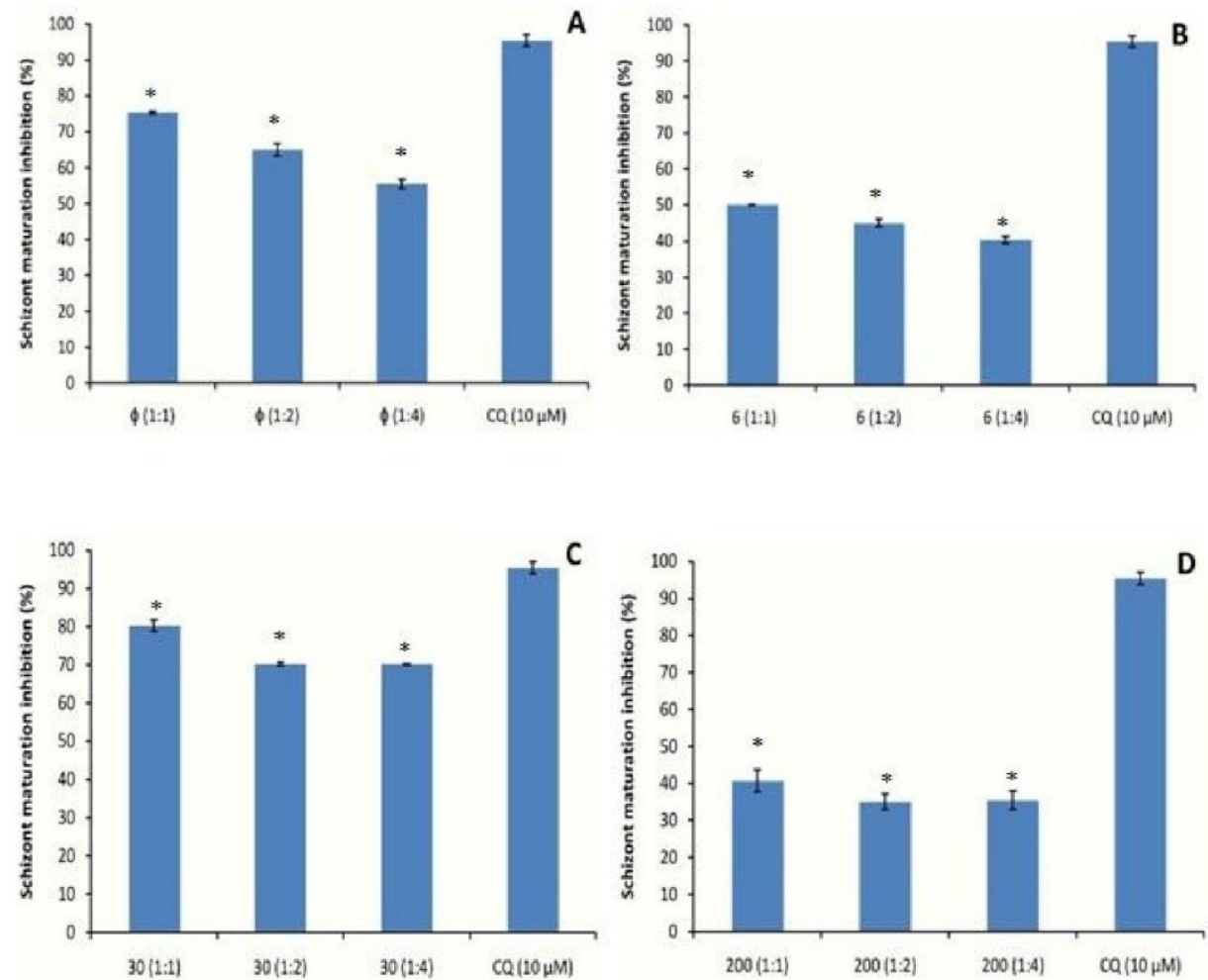

Figure 5: [TT4]Histogram showing schizont maturation inhibition of $P$. berghei in vitro after $21 \mathrm{~h}$ of incubation in the presence of Chel $\phi(\mathrm{A})$ and its various potencies: Chel $6 \mathrm{cH}(\mathrm{B})$, Chel $30 \mathrm{cH} \mathrm{(C),} \mathrm{Chel} 200 \mathrm{cH}$ (D) along with positive control CQ $(10 \mu \mathrm{M})$. Data are expressed as the mean \pm SD of three separate experiments. $\mathrm{p}<0.05$ in comparison to positive control CQ $(10 \mu \mathrm{M})$ is shown as * (statistically significant).

The maximum schizont maturation inhibition of Arsenicum album was observed with Ars $30 \mathrm{cH}(75.5 \pm 2.6$ \%). Ars $6 \mathrm{cH}$ and Ars $200 \mathrm{cH}$ exhibited about 45\% inhibition of schizont maturation (Fig. 7). Many live free merozoites were also observed outside the RBCs in the smears of Ars $200 \mathrm{cH}$-treated wells (Fig. 1E). The maximum schizont maturation inhibition $(95.4 \pm 1.6 \%)$ was observed in the positive control CQ $(10 \mu \mathrm{M})($ Fig. 1F). 


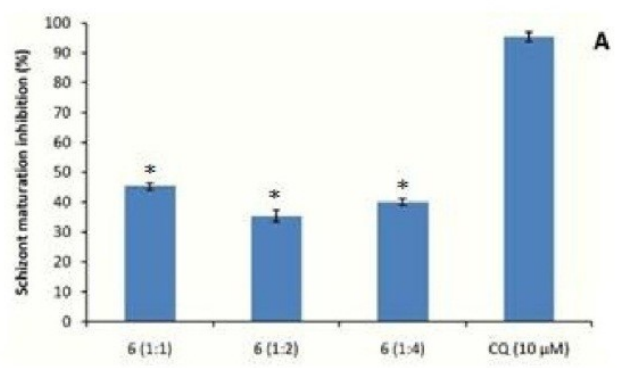

A
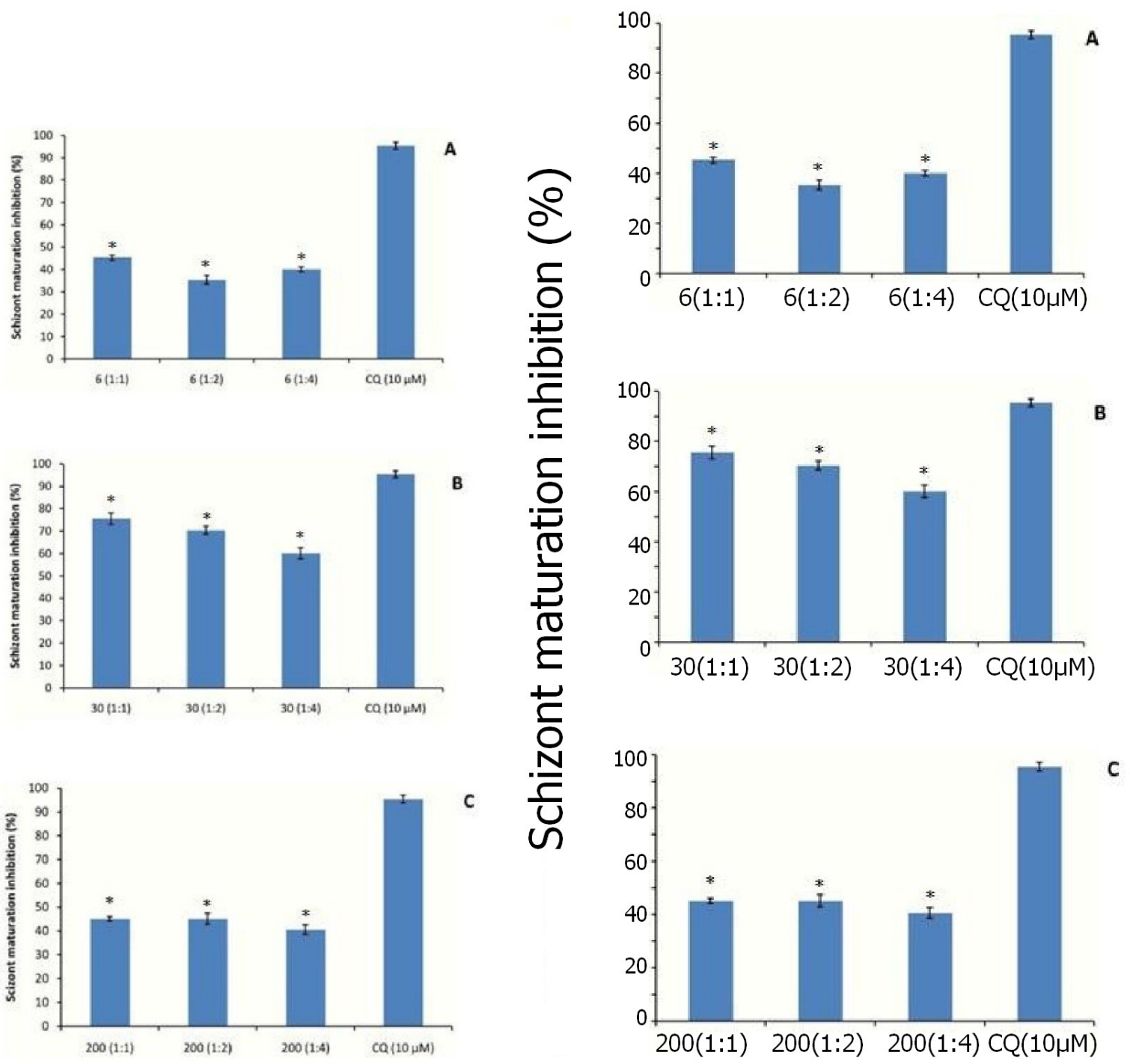

Figure 7: Histogram showing schizont maturation inhibition of $P$. berghei in vitro after $21 \mathrm{~h}$ of incubation in the presence of Ars $6 \mathrm{cH}(\mathrm{A}), \operatorname{Ars} 30 \mathrm{cH}$ (B) and Ars $200 \mathrm{cH}$ (C) along with positive control CQ (10 $\mu$ M). Data are expressed as the mean $\pm \mathrm{SD}$ of three separate experiments. $\mathrm{p}<0.05$ in comparison to positive control $\mathrm{CQ}$ $(10 \mu \mathrm{M})$ is shown as * (statistically significant).

\section{Discussion}

The parasite grows and multiplies in the host's red blood cells, where it modifies the membrane permeability and the cytosolic composition. Erythrocytes serve as a new model to assess drug susceptibility in rodent malaria [12]. The development of techniques for in vitro cultivation of Plasmodium by Trager \& Jensen led to the development of an assay system of drug susceptibility useful in both field and laboratory conditions.

The experiments described in the present study provide evidence and detailed methods for performing erythrocyte invasion/inhibition assays with $P$. berghei in short-term in vitro culture. In vitro antimalarial drug testing is an essential tool for the objective evaluation of the efficacy of antimalarial drugs in concentration-dependent effect on parasite grow. 
Cultivation of human and non-human Plasmodium species in vitro represents a major research breakthrough that paved the way for a better understanding of the parasite, and rapid screening of the effectiveness of antimalarial drugs. In vitro assays are able to test several compounds quickly, at low cost, and require small amounts of the drugs.

The present study points to significant antiplasmodial efficacy in Chin, Chel, and Ars, whereby the maximum percentage of schizont maturation inhibition (80\%) was exhibited by Chin $\phi$ (1:1), Chin $30 \mathrm{cH} \mathrm{(1:1),} \mathrm{Chin,} 30$ cH (1:2) and Chel $30 \mathrm{cH}$ (1:1). The investigated potencies of Ars exhibited weak antiplasmodial efficacy compared to Chin and Chel,, and maximum schizont maturation inhibition of $75 \%$ was found with Ars 30 (1:1) in vitro.

All three investigated homeopathic medicines were found to inhibit $P$. berghei schizont maturation in a dosedependent manner, and significant reduction of the growth of intra-erythrocyte stages of $P$. berghei was observed with decreasing dilutions of $\phi$ and the various potencies $(6 \mathrm{cH}, 30 \mathrm{cH}$ and $200 \mathrm{cH})$.

The presence of free merozoites in the Ars-treated wells points to the ability of the parasite to survive in the given drug pressure. Also Landau et al proposed the presence of latent merozoites being able to penetrate into the erythrocytes [13]. Free merozoites in the circulation are believed not to be vulnerable to the action of antimalarial drugs [14].

The standard drug, CQ at 10- $\mu \mathrm{M}$ concentration exhibited $95.4 \pm 1.6 \%$ inhibition of schizont maturation in vitro in the present study. Tasanor et al developed an in vitro test system for short-term culture of $P$. vivax to assess the parasite's sensitivity to chloroquine. That test system was evaluated in 200 fresh $P$. vivax isolates in an area with satisfactory clinical-parasitological response to chloroquine. At 30 or $42 \mathrm{~h}$ of incubation, 121 isolates (61.5\%) showed adequate control of growth and yielded valid sensitivity tests. Complete inhibition of the parasite development occurred within the concentration range of 40-1280 $\mathrm{nM} \mathrm{[15].}$

The present study points to the considerable antiplasmodial activity of homeopathic drugs against intraerythrocyte growth of $P$. berghei in an in vitro system. Further investigation is needed to explore the in vivo therapeutic efficacy of these medicines, which may support the use of homeopathy in the treatment of malaria.

\section{Acknowlegment}

The authors are grateful to the chairperson and UGC-CAS program of the department of Zoology, Panjab University, Chandigarh for their continued support, and the University Grants commission, New Delhi, India for funding the present work through the Rajiv Gandhi National fellowship to Aswathy Rajan.

\section{References}

[1] Mons B, Siden RE. Laboratory models for research in vivo and in vitro on malarial parasites of mammals: Current status. Parasitol Today. 1990 Jan; 6(1): 3-7.

1. [2] Trager W, Jensen JB. Human malarial parasites in continuous culture. Science. 1976; 193: 673675. 
2. [3] Ladda RL, Aikawa M, Sprinz H. Penetration of erythrocytes by merozoites of mammalian and avain malaria parasites. J Parasitol. 1969 Jun; 55: 633-644.

3. [4] McNally J, Donovan SMO, Dalton JP. P. berghei \& P. chabaudi: Development of simple in vitro erythrocyte invasion assays. Parasitology. 1992; 105: 355-362.

4. [5] Pradines B, Hovette P, Fusai T, Atanda HL, Baret E, Cheval P, Mosnier J, Callec A, Cren J, Amalvict R, Gardiar JP, Rogier C. Prevelence of in vitro resistance to eleven standard or new antimalarial drugs among $P$. falciparum isolates from pointe Noire. Clinical microbiology. 2006 Jun; 44(7): 2404-2408.

5. [6] Bellavite P, Ortolani R, Pontarollo F, pitari G, Conforti A. Immunology and Homeopathy, The Rationale of the 'Similie'. Evid Based Compl Alternat Med. 2007 Feb; 4: 149-163.

6. [7] Davenas EDavenas E, Beauvais FBeauvais F, Amara JAmara J, Oberbaum MOberbaum M, Robinzon BRobinzon B, Miadonna AMiadonna A, Tedeschi ATedeschi A, Pomeranz BPomeranz B, Fortner PFortner P, Belon PBelon P. Human basophil degranulation is not triggered by very dilute antiserum against IgE. Nature. 1988 Jun; 33: 816-818.

7. [8] Witt CM, Bluth M, Albrecht H, Weibhuhn TER, Baumgartner S, Willich SN. The in vitro evidence for an effect of high homeopathic potencies-A systematic review of the literature. Compl Therapies in Med. 2007; 15: 128-138.

8. [9] Weigant FAC, Van Rijin J, Van Wi00jk R. Enhancement of the stress response by minute amounts of cadmium in sensitized Reuber H35 hpatoma cells. Toxicol. 1997; 116: 27-37.

9. [10] Santiyanont R. Parasite identification, counting and staining. In: Application of genetic engineering techniques in tropical diseases, pathogens with special reference to plasmodia. A laboratory manual of selected techniques. UNDP/World Bank/WHO special proram for research and techniques in tropical diseases, Panyim S, Wilairat P, Yuthavong Y, editors. Bangkok, Thailand, WHO; 1985.

10. [11] World Health Organization. In vitro micro test (mark III) for the assessment of response of Plasmodium falciparum to chloroquine, mefloquine, quinine, amodiaquine, sulfadoxine, pyrimethamine and artemisinin. WHO, Geneva. 2001. Report No. CTD/MAL/97, 20.

11. [12] Coy D fitch, Ronald CK Ng, Rekha Chevli. Erythrocytic surface serves as novel determinant of drug susceptibility in rodent malaria. Antimicrob Agent Chemother 1978; 14(2): 185-193.

12. [13] Landau I, Cambie G, Chabaud AG.. Biology of Plasmodium merozoites with special reference to the chemoresistance of Plasmodium falciparum. Ann Parasitol Hum Comp. 1990 Dec; 65: 101-103.

13. [14] Peters W. Drug resistance in malaria parasites of animals and man. Adv Parasitol. 1998; 41: 1-62.

14. [15] Tasanor O, Noedl H, Na-Bangchang K, Congpuong K, Sirichaisinthop J, Wernsdorfer WH. An in vitro system for assessing the sensitivity of Plasmodium vivax to chloroquine. Acta Tropica. 2002 Feb; 83: 4961. 


\title{
Potencial antimalárico de medicamentos homeopáticos contra a maturação de esquizontes de Plasmodium berghei em cultura in vitro"[Article/Dissertation title]"
}

\begin{abstract}
RESUMO
O estudo in vitro da susceptibilidade de Plasmodium a drogras antimaláricas representa um grande avanço nas pesquisas, abrindo novas rotas para o entendimento do parasite e da efetividade de drogas antiomaláricas. Nesse trabalho, realizamos um estudo preliminar da atividade antiplasmódica da tintura mãe $(\phi)$ e várias potências $(6 \mathrm{cH}, 30 \mathrm{cH}, 200 \mathrm{cH})$ dos medicamentos homeopáticos China officinalis (Chin), Chelidonium majus (Chel) e Arsenicum album (Ars), através do estudo in vitro da inibição da maturação de esquizontes. Observamos uma redução significativa do crescimento do estágio intra-eritrócito do $P$. berghei conforme a tintura mãe e demais potências de Chin, Chel e Ars foram diluídas, observando-se um efeito dependente da dose. O máximo de inibição na maturação dos esquizontes (80\%) foi observado com Chin $\phi$

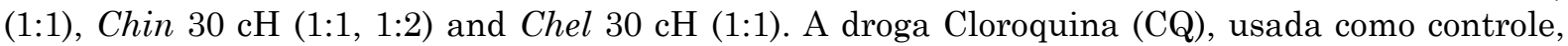
em uma concentração de $10 \mu \mathrm{M}$, exibiu $(95.4 \pm 1.6) \%$ de inibição. Ars 30cH (1:1) também apresentou uma forte eficácia antiplasmódica com $(75.5 \pm 2.6) \%$ de inibição de esquizontes. A presence de merozoites livres com Ars $200 \mathrm{cH}$ e uma fraca atividade inibidora (40-45\%) indicam a habilidade do parasita em sobreviver na presença dessa droga.
\end{abstract}

Palavras-Chaves: Homeopatia; Plasmodium berghei: China officinalis; Chelidonium majus; Arsenicum album

"[Abstract and keywords (in new paragraph)]"

\section{Potencial antimalárico de medicamentos homeopáticos contra la maduração de esquizontes de Plasmodium berghei en cultura in vitro "[Article/Dissertation title]"}

\begin{abstract}
RESUMEN
El estudio in vitro de la susceptibilidad del Plasmodium a drogras anti-maláricas representa un gran avance en la investigación y la apertura de nuevas rutas para la comprensión del parásito y la eficacia de los fármacos antimaláricos. En este trabajo se realizó un estudio preliminar de la actividad antiplasmodial de la tintura madre $(\phi)$ y de diversas potencias $(6 \mathrm{cH}, 30 \mathrm{cH}, 200 \mathrm{cH})$ de los medicamentos China officinalis (Chin), Chelidonium majus (Chel) y Arsenicum album (Ars) mediante el estudio in vitro de la inhibición de la maduración de esquizontes. Se observó una reducción significativa en el crecimiento de la etapa intra-eritrocítica de $P$. berghei conforme la tintura madre y otras potencias de Chin Chel e Ars fueron diluídas, con la observación de un efecto dosis dependiente. La máxima inhibición de la maduración de esquizontes (80\%) se observó con Chin $\phi$ (1:1), Chin $30 \mathrm{cH}(1: 1,1: 2)$ y Chel 30cH (1:1). El contról Cloroquina (CQ), a una concentración de $10 \mu \mathrm{M}$, exhibió $(95,4 \pm 1,6) \%$ de inhibición. Ars $30 \mathrm{cH}(1: 1)$ también mostró una fuerte eficacia en la inhibición de los esquizontes $(75,5 \pm 2,6 \%)$. La presencia de merozoitos libres con Ars $200 \mathrm{cH}$ y una débil actividad inhibidora (40-45\%) indican la capacidad del parásito en sobrevivir en la presencia de esta droga.
\end{abstract}

Palabras-clave: Homeopatia; Plasmodium berghei: China officinalis; Chelidonium majus; Arsenicum album

"[Abstract and keywords (in new paragraph)]" 


\section{(c)) EY-NC-ND Licensed to GIRI}

Support: The research work is financially assisted by University Grants Commission, New Delhi, India through Rajiv Gandhi National Fellowship to Aswathy Rajan. We had full access to all the data in this study and we take complete responsibility for the integrity of the data and the accuracy of the data analysis.

Conflict of interest: authors declare there is no conflict of interest

Received: 10DD December May 2012; Revised: 20 DecemberDD June 2012; Published: 2130 December 2012.

Correspondence author: Dr. Aswathy Rajan, Dep. of Zoology, Panjab University, Chandigarh, zoology1808@gmail.com How to cite this article: Rajan A, Bagai U. Antimalarial potential of some homeopathic medicines against schizont maturation of plasmodium berghei in short term in vitro culture. Int J High Dilution Res [online]. 2012 [cited YYYY Month dd]; 11(41): 224-236<\#from-\#to.>. Available http:/l. http://www.feg.unesp.br/ ojs/index.php/ijhdr/article/view/620/626 